\title{
ERRATUM
}

\section{Erratum to: Metabolic Rates, Growth Phase, and mRNA Levels Influence Cell-Specific Antibody Production Levels from In Vitro- Cultured Mammalian Cells at Sub-Physiological Temperatures}

Rosalyn J. Marchant • Mohamed B. Al-Fageeh •

Michele F. Underhill • Andrew J. Racher •

C. Mark Smales

Published online: 16 April 2011

(C) Springer Science+Business Media, LLC 2011

Erratum to: Mol Biotechnol (2008) 39:69-77

DOI 10.1007/s12033-008-9032-0

In the original publication (volume 39, Issue 1, May 2008), there is an error in the legend for Fig. 6. The description of the shading should read "Cells cultured at $37^{\circ} \mathrm{C}$ (white shade), $32^{\circ} \mathrm{C}$ (black and white squares), and $27^{\circ} \mathrm{C}$ (black shade)."

The online version of the original article can be found under doi:10.1007/s12033-008-9032-0.

R. J. Marchant · M. B. Al-Fageeh · M. F. Underhill ·

C. M. Smales $(\square)$

Protein Science Group, Department of Biosciences, University of Kent, Canterbury, Kent CT2 7NJ, UK

e-mail: c.m.smales@kent.ac.uk

\section{A. J. Racher}

Lonza Biologics plc, 228 Bath Road, Slough SL1 4DX, UK 